\title{
Infection Control in Burn Unit- Role of Nurses and Other Burn Care Personnel
}

\author{
By Dr. Bhupendra Prasad Sarma, Dr. Kabita S Choudhury \\ \& Ms. V S Malingwon
}

Abstract- Introduction: Burn wound infection is the main cause of mortality of burn- injured patients in third world countries. Inadequate infrastructures, paucity of resources, lack of trained manpower, poor personal hygiene are some of the causes of the prevalence of burn wound infection. The Burn Care Team, with the nurse in the pivotal role, contributes a lot in the management and infection control activities.

Materials \& Methods: This study is a retrospective analysis and comparison of the results of treatment before and after application of strict infection control measures in a tertiary Burn Care Unit in 6 years. All patients with Burns ranging from 20\% to 70\% TBSA were included in the study. The data were collected from the format and the records prepared in the burn unit on a day-today basis.

Strictly as per the compliance and regulations of:

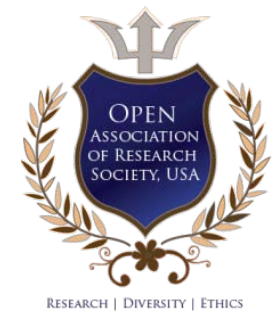

(C) 2022. Dr. Bhupendra Prasad Sarma, Dr. Kabita S Choudhury \& Ms. V S Malingwon. This research/review article is distributed under the terms of the Attribution-NonCommercial-NoDerivatives 4.0 International (CC BY-NC-ND 4.0). You must give appropriate credit to authors and reference this article if parts of the article are reproduced in any manner. Applicable licensing terms are at https://creativecommons.org/licenses/by-nc-nd/4.0/. 


\title{
Infection Control in Burn Unit- Role of Nurses and Other Burn Care Personnel
}

\author{
Dr. Bhupendra Prasad Sarma ${ }^{\alpha}$, Dr. Kabita S Choudhury ${ }^{\sigma} \&$ Ms. V S Malingwon ${ }^{\rho}$
}

Abstract- Introduction: Burn wound infection is the main cause of mortality of burn- injured patients in third world countries. Inadequate infrastructures, paucity of resources, lack of trained manpower, poor personal hygiene are some of the causes of the prevalence of burn wound infection. The Burn Care Team, with the nurse in the pivotal role, contributes a lot in the management and infection control activities.

Materials \& Methods: This study is a retrospective analysis and comparison of the results of treatment before and after application of strict infection control measures in a tertiary Burn Care Unit in 6 years. All patients with Burns ranging from $20 \%$ to $70 \%$ TBSA were included in the study. The data were collected from the format and the records prepared in the burn unit on a day-to-day basis.

Results: The five bedded burn unit with a total of 187 admitted patients had an overall mortality of $33.5 \%$ in the first three years. The cause of death was $84.2 \%$ due to septicemia, $5.2 \%$ due to ARF, $6 \%$ due to burn-shock, and $4.6 \%$ due to ARDS. The average bed days of the patients were 35.5days. MDR bacteria like Acinetobacter Boumanii, Pseudomonas Aeruginosa and Klebsiella pneumonae accounted for $88 \%$ of the prevalent organisms in burn wounds.

Infection control measures like renovation of the unit to isolate each patient, strict compliance to hand washing and use of protective clothing by the caregiver, use of disposable items, autoclaving of linens and use of antibiotics according to culture-sensitivity reports were strictly imposed. The treatment protocol was also suitably modified. The nurses were responsible for strict compliance with the measures.

Analysis of results in the next three years revealed reduced mortality to $26.4 \%$ amongst 333 admitted patients. The causes of death were septicaemia-55\%, ARF-16.5\%, burn shock $-20.3 \%$ and ARDS $-8.2 \%$. There wasa substantial reduction in MDR bacteria in wound cultures. The average hospital stay of the patients came down to 24.4 days.

Conclusion: It was concluded that strict compliance to infection control measures could reduce burn wound infection and consequent mortality and morbidity of burn patients.

\section{INTRODUCTION}

nfection of the burn wounds is the leading cause of mortality and morbidity in burns. Inadequate infrastructures, paucity of resources, lack of trained manpower, poor personal hygiene are some of the causes of the prevalence of burn wound infection. 75\% of all deaths in burns exceeding $40 \%$ TBSA is due to

Corresponding Author a: Senior Consultant Surgeon \& In Charge, Burn Unit, NEMCARE Hospital, Guwahati.e-mail: bpsarmadr@gmail.com Author $\sigma:$ Junior Consultant, Burn Unit, NEMCARE Hospital, Guwahati. Author p: Nursing in Charge, Burn Unit, NEMCARE Hospital, Guwahati. burn wound infection. Hence infection remains one of the most challenging concerns for the burn team. The importance of preventing infection has been recognized by organized burn care units and hence strict antiseptic and aseptic measures have been followed. This included use of sterile gloves and dressing materials, wearing masks for dressing changes, and separation of patients, either using separate rooms or cubicles[1]. The development of infection depends on the presence of conditions, like- a source of organisms, a mode of transmission, and the susceptibility of the patient. Sources of organisms are found in the patient's own endogenous flora, from exogenous sources in the environment, and from the burn care personnel. The burn wound represents a susceptible site for opportunistic colonization by organisms of endogenous and exogenous origin. Patient factors such as age, the extent of injury, and depth of burn, in combination with microbial factors such as type and number of organisms, enzyme and toxin production, and motility determine the likelihood of invasive burn wound infection [2]. The burn wound is initially colonized predominantly with gram-positive organisms, which are replaced within a week by antibiotic-susceptible gramnegative organisms. If wound closure is delayed, infection is inevitable, requiring treatment with broadspectrum antibiotics. This results in infection by yeasts, fungi, and antibiotic-resistant bacteria. The principal defenses of the patient against infection: namely, physical defenses, nonspecific immune responses, and specific immune responses may be altered by the use of invasive devices, such as endotracheal tubes, intravascular catheters and urinary catheters, and lead to patient's susceptibility to infection.[1] Incidence of infection is also affected by the size of the patient's burn injury.

In the last two decades, much progress has been made in the control of burn wound infection and nosocomial infections (NI) in severely burned patients. The continually changing epidemiology is partially related to greater understanding of and improved techniques for burn patient management as well as effective hospital infection control measures. With the advent of antimicrobial chemotherapeutic agents, infection of the wound site is now not as common as, for example, urinary and bloodstream infections. Universal application of early excision of burned tissues has made a substantial improvement in the control of wound- 
related infections in burns. Additionally, the development of new technologies in wound care have helped to decrease morbidity and mortality in severe burn victims [3]

Infection of the burn wound may result in permanent scarring, disfigurement and disability These can have serious personal and financial implications for both the burn victim and their dependents. [4]

Empiric antimicrobial therapy to treat fever should be discouraged because burn patients often have fever secondary to the systemic inflammatory response to burn injury. Prophylactic antimicrobial therapy is recommended only for coverage of the immediate perioperative period of excision or grafting of the burn wound to cover the risk of transient bacteremia.

Burn wound infection is the main cause of mortality of burn-injured patients in third world countries. The Burn Care Team, with the nurse in the pivotal role, contributes a lot in the management and infection control activities. The present study was done in a tertiary care, 5 bedded burn unit at NEMCARE Hospital, Guwahati, located in the North Eastern part of India. The unit being small, with inadequate space and trained manpower, there was high infection rate with consequent increased morbidity and mortality of the burn patients. The burn unit was then renovated, increasing the number of beds to 10 and making it more spacious with isolated beds. The number of resident doctors, nurses and paramedics were also increased, along with the provision of intense in-house training on modern management protocol on burns and best practices on infection control. Strict antiseptic and aseptic measures were implemented with the provision of barrier nursing of the infected cases. The measures proved useful with decrease in infection rate and improved result of treatment. The aim of our study was to find out the overall morbidity and mortality pattern visa-vis the infection rate of the burn patients treated in a specified period. We also wanted to compare the infection rate, morbidity and mortality before and after renovation and application of strict aseptic measures in the burn unit.

\section{il. Materials \& Methods}

This study was a retrospective analysis and comparison of the results of treatment before and after application of strict infection control measures in the tertiary Burn Care Unit in a period of 6 years. To compare the results of treatment before and after renovation of the burn unit, the period was divided into two blocks- Block A- from January 2014 to December 2016- before renovation and Block B- January 2017 to December 2019- after renovation and implementation of strict antiseptic measures. In Block A, all types of burninjured patients were treated in the unit with standard protocols-fluid resuscitation was done by using Parkland formula, burn wounds were treated by closed dressing with $1 \%$ Silver Sulphadiazine and collagen or by using newer wound covers like Collagen sheet, Silver Ion dressing and Nano-Crystalline Silver dressing, depending on the type and nature of the wound. A broad-spectrum systemic antibiotic, mostly of secondgeneration cephalosporin group, was used prophylactically in all cases. Early excision and skin grafting was also done in selected cases (below 50\%TBSA burn) with full- thickness burns. In Block B, the standard protocol of resuscitation remaining same, the burn wound covers were used more frequently. A major deviation in the protocol in this block was, discontinuation of prophylactic systemic antibiotic cover in all fresh burn cases. Systemic antibiotics were reserved only for perioperative cases and those having positive bacterial cultures. Early Excision and Skin Grafting was done in most of the cases with fullthickness burns upto 60\% TBSA. Wound swabs were taken for culture and sensitivity on day 1,7,14 and 21 days or more frequently depending upon the nature of the wounds. Blood, urine, sputum, central venous catheter tip or urinary catheter tips were sent for culture and sensitivity tests, depending upon the types of symptoms and system involvement in both the Blocks.

The burn unit recorded all relevant treatment data in a format, which was kept in the patients' bed tickets. The information was then computerized to make a database for each patient. The relevant data were collected from the computerized database of the admitted patients in the burn unit during the said period.

The study included 520 patients in 6 years. The inclusion criteria were (i) Patients with $20 \%$ to $70 \%$ TBSA burn, (ii) Patients between 10 and 70 years of age (iii) patients having no serious comorbidities. All patients in extremes of ages and with serious comorbidities, like uncontrolled diabetes, severe hypertension, heart disease, liver disease and renal failure were excluded from the study. Committee.

The study was approved by the Hospital Ethical

\section{Data Analysis}

Data was entered and analyzed in R Studio software version 1.4.1717 for windows. For the difference in categorical variables, the Pearson Chisquare $\left(\chi^{2}\right)$ test was used. A value of $P<0.05$ was considered statistically significant. For data analysis, mean and SD were used as descriptive statistics. As the number of patients was different in two blocks, we have taken for analysis a sample size of 100 for each block.

\section{Results}

A total of 520 patients were included in the study period; 230 of them were males and 290 were females. In Block A-the first three years before 
renovation had 187 patients, 111 females and 77 males and in Block B- the next three years after renovation and application of strict aseptic measures - had 333 patients; 179 females and 154 males (Fig I). Out of included group of patients, the majority i.e., 309 numbers $(59.4 \%)$ of patients were in the age group of 19 to 40 years. The mean age and standard deviations were 34.73 years\& 13.86 for Block $A$ and 33.67 years \& 14.04 for Block $B$ respectively (Table I). While analyzing the percentage of TBSA burn, it was evident that, in Block $A$, there were 110 (58.8\%) patients with 20-40\% \&77 (41.1\%) with $41-70 \%$ TBSA burn and in Block B, there were 182 (54.5\%) with 20-40\% and 151 (45.3\%) with $41-70 \%$ burn (Fig II). Analysis of cases on the day of admission revealed that, there were 350 (67.3\%) fresh and non-infected patients, 125 (24.0\%) mildly infected patients and 45 (8.6\%) patients with invasive infections, in the series. There were no significant variations in the number of non-infected and infected patients in the two blocks (Table II). Analysis of methods of treatment used revealed that, $45.4 \%$ patients in Block $A$ and $47.1 \%$ in Block $B$ were treated with newer burn wound covers, $11.7 \%$ patients in Block $A$ and $6.0 \%$ patients in Block $B$ were dressed with $1 \%$ Silver Sulphadiazine+ Collagen cream; while a somewhat increased number of patients were treated with Early Excision and Skin Grafting in Block B (38.1\% in Block B and $27.8 \%$ patient in Block $A)$. The methods of treatment in both the blocks were almost the same as the differences were not statistically significant (Table III).

a) Infection

Analysis of organ dysfunction due to infection revealed that though there was no significant difference in incidence of wound infection, UTI and pneumonia, incidence of septicemia showed significant reduction $(P=0.04)$ in Block $B(15.0 \%)$ compared to Block $A$ (28.3\%). The total number of patients showing organisms on cultures were 122 (63.5\%) in Block $A$ and $180(54.0 \%)$ in Block B; depicting a decrease in infection rate in later period (though not statistically significant: $\mathrm{P}=0.38$ ) (Table IV). Going through the types of organisms isolated in cultures, it was evident that 282 (93.3\%) of them were Gram-negative bacteria. Only 17 (5.6\%) were Gram-positive bacteria and 3 (0.9\%) were fungi (Candida albicans). Out of the Gram-negative bacteria, 251 (83.1\%) were Acinetobacter Boumanii, Pseudomonas Aeruginosa and Klebsiella Pneumonae. Similar types of organisms were detected in both the Blocks (Fig III).

\section{b) Mortality}

In the entire period of our study, out of a total of 520 patients, $151(29.0 \%)$ patients died. Though statistically not significant, the overall percentage of death in Block B was less (88 patients died out of 333 i.e., $26.4 \%$ ) than that of Block $A$ (63 patients died out of 187 i.e., 33.5\%). The analysis of causes of death revealed that there was a significant reduction $(P=0.01)$ of death from septicemia in Block B (55.0\%) in comparison to Block A (84.3\%). Due to a greater number of extensive burns in Block $B$, there were a significant increase in the percentage of death due to burn shock (20.3\% in Block B \& $6.0 \%$ in Block $A$ ) and acute renal failure (16.5\% in Block $B$ \& $5.2 \%$ in Block $A)$ (Table $\mathrm{V}$ ). The analysis of number of deaths according to the percentage of TBSA burns revealed that there was a significant reduction ( $P=0.014$ ) of death of patients having $20-40 \%$ burns in Block $B(15$ numbers- $4.5 \%)$ in comparison to Block A(33 numbers- 17.5\%) (Table VI).

\section{c) Morbidity}

Analysis of the hospital bed days occupancy by the patients in both the blocks revealed that $66.7 \%$ of patients stayed beyond two weeks in Block A, while $43.5 \%$ of patients only stayed beyond two weeks in Block B. Though not statistically significant, the average bed day occupancy of the patients in Block $B$ was less (24.5 days), compared to that of Block $A$ (35.5 days) (Table VII).

\section{Discussion}

Burn wound infection (BWI) in the burn care unit is the primary cause of mortality and morbidity of burn patients. The increased number of hospital bed-day occupancy due to infection, leads to the increase in the cost of treatment. BWI is more prevalent in the environment, which is overcrowded, with poor air circulation and without facility for isolation of the patients. Poor personal hygiene of the burn care personnel and the patients are added factors in acquiring BWI. In one of the studies by Peck M D etal it was inferred that, burned patient is at a high risk for nosocomial infection $(\mathrm{NI})$ as a result of the nature of the burn injury itself, the immune-compromising effects of burns, prolonged hospital stays and intensive diagnostic and therapeutic procedures [5]. In our study also environmental and human factors resulted in increased infection rates in the first three years. Increased infection rate was also responsible for high mortality of patients with $20-40 \%$ TBSA burn in Block A, though there wasa greater number of patients (58.8\%) with relatively less areas of burns in this group. This fact is in contrast to a study done in a tertiary care burn unit in Northern India, where it was found that the mortality was related to the percentage of TBSAburn. Thirteen out of 18 patients who had TBSAburn more than $60 \%$ died as compared to 5 out of 31 with TBSA burn less than $40 \%$ in their study [6]. Though, around $66 \%$ of fresh cases, without infection, reported in both the blocks in our study, the infection rates and death due to septicemia was found to be more in Block $A$ than those of Block B. The reduction of the number of death due to septicemia in Block B was the result of implementation of strict aseptic measures by the burn care personnel. This statement 
conforms with the study done in Northern India by Neelam Taneja et al. They stated that better compliance with handwashing and barrier nursing techniques, stricter control over disinfection and sterilization practices and usage of broad-spectrum antibiotics, and reduction of the environmental contamination with $\mathrm{S}$. aureus is required to reduce the HAl rates [6].

The reduction of multidrug-resistant organisms and the infection rates in Block B, in our study, was the result of a limitation of the use of prophylactic antibiotics. This fact was corroborated by Gerner J S et al. who suggested that the burn surgeons should minimize the use of prophylactic antimicrobial agents and apply standardized written criteria, such as those developed by the CDC and by Garner et.al [7]. Joan M Weber also stated that systemic antimicrobial treatment must be thoughtfully considered in the care of burn patients to prevent the emergence of resistant organisms. The burn wound will always be colonized with organisms until wound closure is achieved. Administering systemic antimicrobials will not eliminate this colonization, but promote the emergence of the resistant organisms. If antimicrobial therapy is indicated to treat a specific infection, it should be tailored to the specific susceptibility patterns of the organisms as soon as this information is available [8].

Different types of the burn wounds were covered by new wound covers like Collagen sheet, Silver lon dressing and Nano-Crystalline Silver dressing, in almost equal number of cases, in both blocks. But an increased number of cases were treated with Early Excision and Skin Grafting in Block B, resulting in the reduction of the infection rate and mortality, in our study. This fact has been corroborated bya number of studies on the subject, which stated that 'Early burn wound excision, performed within the first few days after burn injury, resulted in improved survival and infection control in severely burned patients.' $[9,10,11]$.

In our study, the wound swab cultures revealed the majority (93.3\%) of Gram-negative bacteriaPseudomonas Aeruginosa heading the list, followed by Acitobacter Boumanii, Klebsiella Pneumonae and EColi. We had a smaller number of Staphylococcal infection, but and no streptococcus infection in our study. This finding is somewhat in conformity with the study of OOncul et.al. who had Pseudomonas aeruginosa (57\%), Acinetobacter Boumanii (21\%) and Staphylococcus aureus (14\%) as the most common resistant organisms isolated [12]. Pia Appelgren et.al. had different findings in their study- themost common micro-organisms were the coagulase-negative staphylococci and methicillin-sensitive Staphylococcus aureus in their series [13]. Neelam Taneja et al also had Staphylococcus aureus, Pseudomonas aeruginosa and $\beta$-hemolytic streptococci (BHS) as the most frequent organisms causing hospital-acquired infection [6].
The cause of mortality of the majority of the patients in our study was septicemia, though the percentage was more $(84.2 \%)$ in Block $A$ than Block B (55\%). Tancheva Det al. had similar findings in their study, where approximately $73 \%$ of all deaths within the first 5-day post-burn is shown to be directly or indirectly caused by septic processes [14]. The average hospital days (length of hospitalization) of the patients in block $B$ was less (24.5days) in comparison to Block $A(35.5$ days), because of lower rate of infection in Block $B$ in our study. This result of our study is in line with the findings of $\mathrm{O}$ Oncul et, al. They stated that, the mean age $(38+/-21 \mathrm{yr})$, the mean length of hospitalization $(45.06+/-11.67$ days) and the total burned surface area (TBSA) $(34.58+/-18.46 \%)$ of the patients with $\mathrm{NI}$ (Nosocomial Infection) were higher than those of the patients with non- $\mathrm{NI}(23+/-17 \mathrm{yr}),(16.38+/-11.14$ days) and (12.44 +/- 8.69\%) $(P=0.03, \quad P=0.001$, $\mathrm{P}=0.01$ ) respectively [12].

\section{Conclusion}

Burn wound infection is the main cause of mortality of burn injured patients in the third world countries. Inadequate infrastructures, paucity of resources, lack of trained manpower and poor personal hygiene are the multiple factors, which contribute to its occurrence and perpetuation. Thoughtful planning to eliminate these factors can reduce the incidences of burn wound infection to a large extent. The active involvement of the burn care personnel in strict compliance to infection control measures can reduce burn wound infection and consequent mortality and morbidity of burn patients.

\section{ACKNOWLEDGEMENT}

The authors are thankful to the Management of NEMCARE Hospital, Guwahati for providing the help and support necessary for carrying out the study and also for allowing publication of the results. Our sincere thanks are also due to the nursing staff and colleagues of the Burn Unit of NEMCARE Hospital for their active participation in the study. We are also thankful to Mr. Hiranjyoti Sarma for helping us in statistical analysis. 
From 2014 to 2019

Total Number of patients - $\mathbf{5 2 0}$

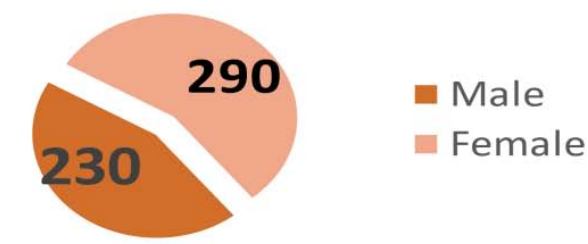

Block A 2014 to 2016

Total patients- 187

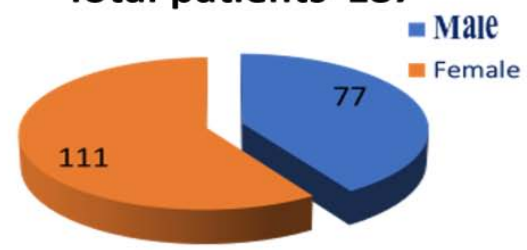

Block B 2017 to 2019

Total patient $-\mathbf{3 3 3}$

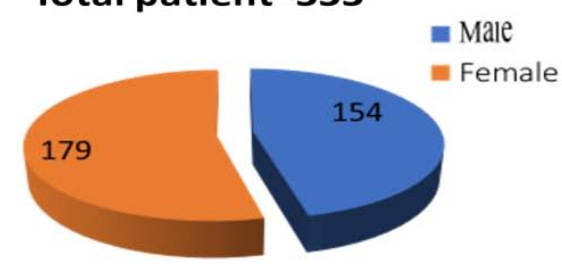

Fig I

Table I

Age of patients in different Blocks

\begin{tabular}{|c|c|c|c|c|c|c|c|}
\hline Block & $\begin{array}{c}10-18 \\
\text { Yrs }\end{array}$ & $\begin{array}{c}19-30 \\
\text { Yrs }\end{array}$ & $\begin{array}{c}31-40 \\
\text { Yrs }\end{array}$ & $\begin{array}{c}41-50 \\
\text { Yrs }\end{array}$ & $\begin{array}{c}51-60 \\
\text { Yrs }\end{array}$ & $\begin{array}{c}61-70 \\
\text { Yrs }\end{array}$ & Total \\
\hline $\begin{array}{c}\text { 2014-2016 } \\
\text { Block A }\end{array}$ & 21 & 53 & 65 & 20 & 15 & 13 & 187 \\
\hline $\begin{array}{c}\text { 2017-2019 } \\
\text { n1 }\end{array}$ & 54 & 87 & 104 & 42 & 29 & 17 & 333 \\
\hline
\end{tabular}

ВIOCK В

\begin{tabular}{|l|l|l|l|l|l|l|l|}
\hline 44 & 30 & 520 & $2014-2019$ & 75 & 140 & 169 & 62 \\
\hline
\end{tabular}

Mean age- 34.73 years and SD 13.86 in Block A Mean age -33.67 years \& SD -14.04 in Block B 
Number of Patients According to TBSA Burn 2014 -2019 Block A-187 Block B -333

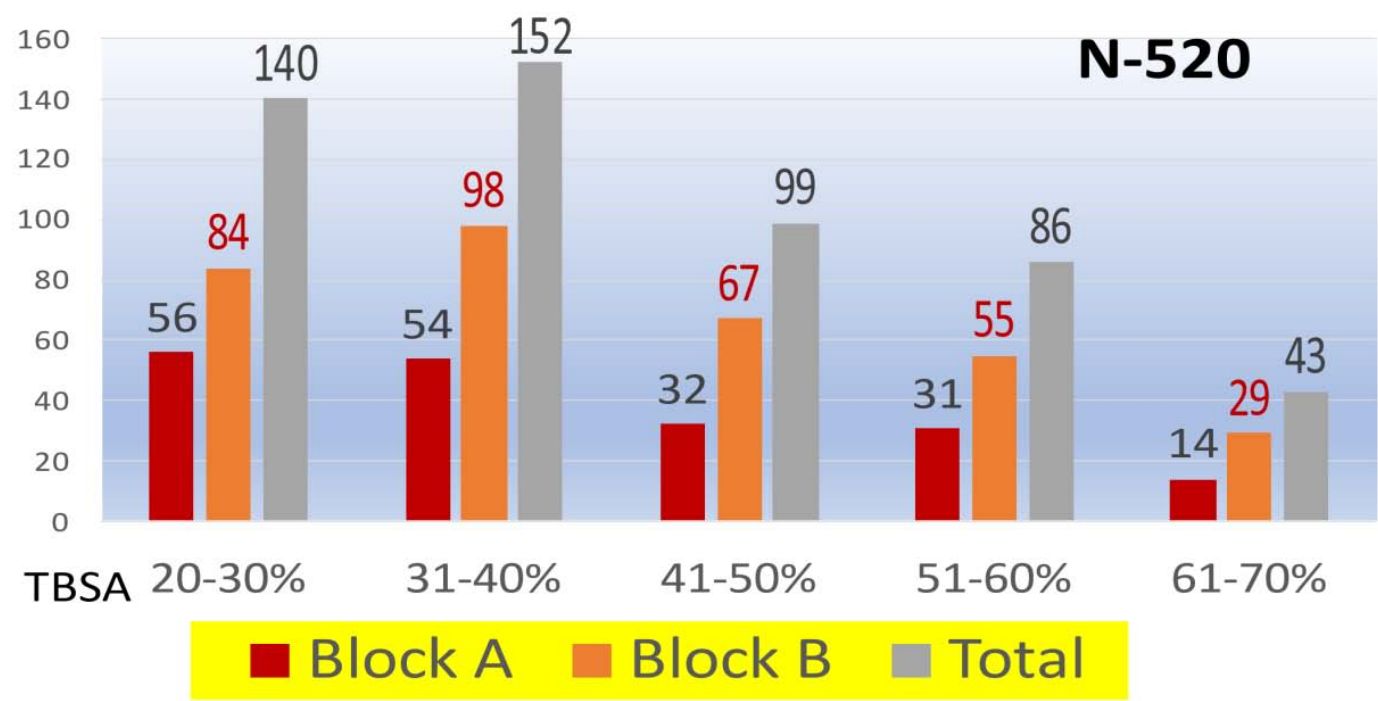

Block A- 2014-2016 Block B - 20172019 Total - 2014- 2019

Fig II

Table /l

Number of Fresh and Infected patients on admission day

\begin{tabular}{|c|c|c|c|c|}
\hline Block & Fresh cases & Mildly infected & $\begin{array}{c}\text { Invasive } \\
\text { infection }\end{array}$ & Total \\
\hline Block A & $66.0 \%$ & $28.0 \%$ & $6.0 \%$ & 187 \\
\hline $2017-2016$ & 124 & 52 & 11 & 333 \\
\hline Block B & 226 & 73 & 34 & \\
\hline $2014-2019$ & $35.0 \%$ & $22.1 \%$ & $10.0 \%$ & 520 \\
\hline Overall & $67.3 \%$ & 125 & 45 & \\
\hline
\end{tabular}

Figures in the parentheses show row-wise percentages 


\section{Methods of treatment}

\begin{tabular}{|c|c|c|c|c|c|c|c|}
\hline \multirow[t]{2}{*}{ Block } & \multirow{2}{*}{$\begin{array}{l}\text { Dressing } \\
\text { with } \\
\text { SS D + } \\
\text { Collagen } \\
\text { cream }\end{array}$} & \multicolumn{3}{|c|}{ Use of Burn wound covers } & \multirow{2}{*}{$\begin{array}{c}\text { Early } \\
\text { Excision \& } \\
\text { Skin- } \\
\text { grafting }\end{array}$} & \multirow{2}{*}{$\begin{array}{l}\text { Combined } \\
\text { methods }\end{array}$} & \multirow[t]{2}{*}{ Total } \\
\hline & & $\begin{array}{c}\text { Collagen } \\
\text { sheet }\end{array}$ & $\begin{array}{c}\text { Silver lon } \\
\text { dressing }\end{array}$ & $\begin{array}{l}\text { Nano-cryst. } \\
\text { Silver } \\
\text { dressing }\end{array}$ & & & \\
\hline $\begin{array}{c}20142016 \\
\text { Block A }\end{array}$ & $\begin{array}{c}22 \\
11.7 \%\end{array}$ & $\begin{array}{c}41 \\
21.9 \%\end{array}$ & $\begin{array}{c}32 \\
17.1 \%\end{array}$ & $\begin{array}{c}12 \\
6.4 \%\end{array}$ & $\begin{array}{c}52 \\
27.8 \%\end{array}$ & $\begin{array}{c}28 \\
14.9 \%\end{array}$ & 187 \\
\hline $\begin{array}{c}2017-2019 \\
\text { Block B }\end{array}$ & $\begin{array}{c}20 \\
6.0 \%\end{array}$ & $\begin{array}{c}69 \\
20.7 \%\end{array}$ & $\begin{array}{c}57 \\
17.1 \%\end{array}$ & $\begin{array}{c}31 \\
9.3 \%\end{array}$ & $\begin{array}{c}127 \\
38.1 \%\end{array}$ & $\begin{array}{c}29 \\
8.7 \%\end{array}$ & 333 \\
\hline $\begin{array}{l}\text { Chi } \\
\text { Squared } \\
\text { P value }\end{array}$ & $\begin{array}{l}1.836 \\
0.175\end{array}$ & $\begin{array}{l}0.033 \\
0.8541\end{array}$ & 0 & $\begin{array}{l}0.535 \\
0.464\end{array}$ & $\begin{array}{l}1.61 \\
0.205\end{array}$ & $\begin{array}{l}1.6288 \\
0.202\end{array}$ & \\
\hline $\begin{array}{c}20142019 \\
\text { Overall }\end{array}$ & $\begin{array}{c}42 \\
8.0 \%\end{array}$ & $\begin{array}{c}110 \\
21.1 \%\end{array}$ & $\begin{array}{c}89 \\
17.1 \%\end{array}$ & $\begin{array}{c}43 \\
8.2 \%\end{array}$ & $\begin{array}{c}179 \\
34.4 \%\end{array}$ & $\begin{array}{c}57 \\
10.9 \%\end{array}$ & 520 \\
\hline
\end{tabular}

Figures in the parentheses show row- wise percentages

Table IV

Infection causing organ dysfunction

\begin{tabular}{|c|c|c|c|c|c|}
\hline Block & $\begin{array}{l}\text { Wound } \\
\text { Infection }\end{array}$ & Septicaemia & UTI & Pneumonia & $\begin{array}{l}\text { Total Infected } \\
\text { patients }\end{array}$ \\
\hline $\begin{array}{c}\text { 1914-1916 } \\
\text { Block A }\end{array}$ & $\begin{array}{c}28 \\
14.9 \%\end{array}$ & $\begin{array}{c}53 \\
28.3 \%\end{array}$ & $\begin{array}{c}34 \\
18.1 \%\end{array}$ & $\begin{array}{c}7 \\
3.7 \%\end{array}$ & $\begin{array}{l}122(63.5 \%) \\
\text { (Out of 187) }\end{array}$ \\
\hline $\begin{array}{c}1917- \\
2019 \\
\text { Block B }\end{array}$ & $\begin{array}{c}49 \\
14.7 \%\end{array}$ & $\begin{array}{c}50 \\
15.0 \%\end{array}$ & $\begin{array}{c}52 \\
15.6 \%\end{array}$ & $\begin{array}{c}29 \\
8.7 \%\end{array}$ & $\begin{array}{l}180(54.0 \%) \\
\text { (Out of } 333 \text { ) }\end{array}$ \\
\hline $\begin{array}{c}\text { Chi Squared } \\
\text { P-Value }\end{array}$ & $\begin{array}{l}0.001 \\
0.97\end{array}$ & $\begin{array}{l}4.09 \\
0.04\end{array}$ & $\begin{array}{l}0.19 \\
0.67\end{array}$ & $\begin{array}{l}2.02 \\
0.16\end{array}$ & $\begin{array}{l}0.77 \\
0.38\end{array}$ \\
\hline $\begin{array}{c}\text { 2014-2019 } \\
\text { Overall }\end{array}$ & $\begin{array}{c}141 \\
46.6 \%\end{array}$ & $\begin{array}{c}106 \\
35.0 \%\end{array}$ & $\begin{array}{c}54 \\
17.8 \%\end{array}$ & $\begin{array}{c}1 \\
0.3 \%\end{array}$ & $\begin{array}{l}302(58.0 \%) \\
\text { (Out of } 520)\end{array}$ \\
\hline
\end{tabular}

Figures in the parentheses show row- wise percentages 


\section{Organisms Isolated in culture (2014 -2019)}

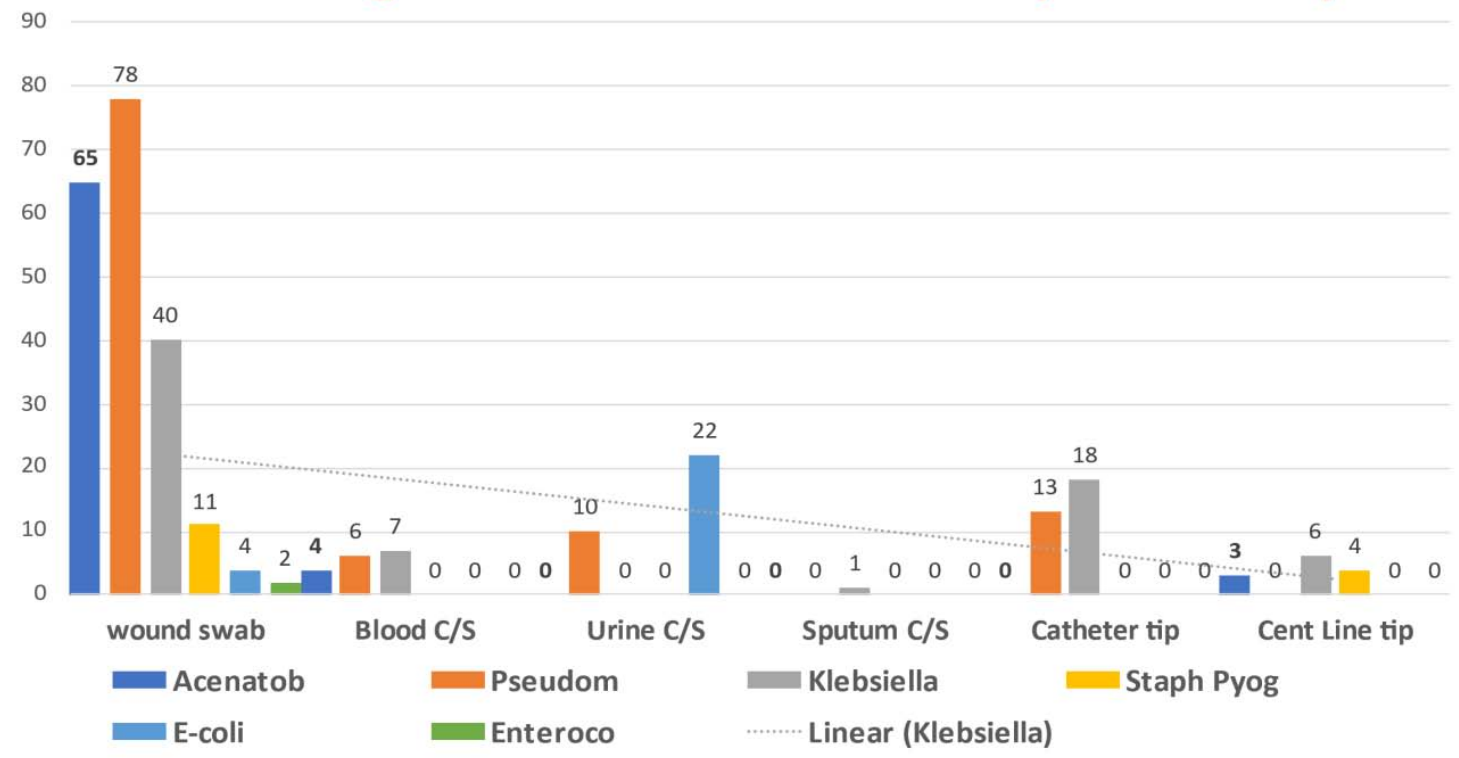

Gram-ve Org. - 282 (93.3\%) Gram +ve Org.- 17 (5.6\%) Candida - 3 (0.9\%)

Acinatobacter+ Pseudomon + Klebsiella - 251 (83.1\%)

Fig III

Table $\mathrm{V}$

\section{Causes of Death}

\begin{tabular}{|c|c|c|c|c|c|}
\hline Block & $\begin{array}{c}\text { Septice } \\
\text { mia }\end{array}$ & $\begin{array}{l}\text { Burn } \\
\text { Shock }\end{array}$ & $\begin{array}{l}\text { Acute } \\
\text { Renal } \\
\text { Failure }\end{array}$ & ARDS & $\begin{array}{l}\text { Total } \\
\text { Death } \\
\text { \& PC }\end{array}$ \\
\hline $\begin{array}{c}\text { 1914-1916 } \\
\text { Block A }\end{array}$ & $\begin{array}{c}53 \\
84.2 \%\end{array}$ & $\begin{array}{c}4 \\
6.0 \%\end{array}$ & $\begin{array}{c}3 \\
5.2 \%\end{array}$ & $\begin{array}{c}3 \\
4.6 \%\end{array}$ & $\begin{array}{c}63 \\
33.5 \%\end{array}$ \\
\hline $\begin{array}{c}1917-2019 \\
\text { Block B }\end{array}$ & $\begin{array}{c}48 \\
55.0 \%\end{array}$ & $\begin{array}{c}18 \\
20.3 \%\end{array}$ & $\begin{array}{c}14 \\
16.5 \%\end{array}$ & $\begin{array}{c}7 \\
8.2 \%\end{array}$ & $\begin{array}{c}88 \\
26.4 \%\end{array}$ \\
\hline $\begin{array}{c}\text { Chi Squared } \\
\text { P-Value }\end{array}$ & $\begin{array}{l}6.125 \\
0.01\end{array}$ & $\begin{array}{l}7.775 \\
0.005\end{array}$ & $\begin{array}{l}5.884 \\
0.01\end{array}$ & $\begin{array}{l}1.012 \\
0.314\end{array}$ & $\begin{array}{l}0.842 \\
0.359\end{array}$ \\
\hline $\begin{array}{c}\text { 2014-2019 } \\
\text { Overall }\end{array}$ & $\begin{array}{c}99 \\
65.3 \%\end{array}$ & $\begin{array}{c}23 \\
15.0 \%\end{array}$ & $\begin{array}{c}19 \\
12.5 \%\end{array}$ & $\begin{array}{c}10 \\
6.9 \%\end{array}$ & $\begin{array}{c}151 \\
29.0 \%\end{array}$ \\
\hline
\end{tabular}

Figures in the parentheses show row-wise percentages 
Table VI

\section{Number and Death According to Percentage of Burns}

\begin{tabular}{|c|c|c|c|c|c|c|c|}
\hline Block & & $20-30 \%$ & $31-40 \%$ & $41-50 \%$ & $51-60 \%$ & $61-70 \%$ & Total \\
\hline $2014-2016$ & Number & 56 & 54 & 32 & 31 & 14 & 187 \\
\hline Block A & Death & $\begin{array}{l}8 \\
4.2 \%\end{array}$ & $\begin{array}{l}25 \\
13.3 \%\end{array}$ & $\begin{array}{l}11 \\
5.8 \%\end{array}$ & $\begin{array}{l}10 \\
5.3 \%\end{array}$ & $\begin{array}{l}9 \\
4.8 \%\end{array}$ & $\begin{array}{l}63 \\
33.5 \%\end{array}$ \\
\hline 2017-2019 & Number & 84 & 98 & 67 & 55 & 29 & 333 \\
\hline Block B & Death & $\begin{array}{l}4 \\
1.2 \%\end{array}$ & $\begin{array}{l}11 \\
3.3 \%\end{array}$ & $\begin{array}{l}18 \\
5.4 \%\end{array}$ & $\begin{array}{l}36 \\
10.8 \%\end{array}$ & $\begin{array}{l}19 \\
5.7 \%\end{array}$ & $\begin{array}{l}88 \\
26.4 \%\end{array}$ \\
\hline \multirow[t]{2}{*}{$\begin{array}{l}\text { Statistical } \\
\text { Analysis }\end{array}$} & $\begin{array}{l}\text { Chi } \\
\text { Squared }\end{array}$ & 1.667 & 6.024 & 0.014 & 1.878 & 0.077 & 0.841 \\
\hline & $P$ value & 0.196 & 0.014 & 0.905 & 0.1705 & 0.781 & 0.359 \\
\hline \multirow{2}{*}{$\begin{array}{l}2014- \\
2019\end{array}$} & Number & 143 & 149 & 99 & 86 & 43 & 520 \\
\hline & Death & 12 & 36 & 29 & 46 & 28 & 151 \\
\hline
\end{tabular}

Figures in the parentheses show row-wise percentages

Table VII

\section{Hospital Bed Days in two Blocks}

\begin{tabular}{|c|c|c|c|c|c|c|c|}
\hline Block & Hospital Days & $\begin{array}{l}\text { TBSA } \\
\text { Burn } \\
20- \\
40 \%\end{array}$ & $\begin{array}{l}\text { TBSA Burn } \\
41-60 \%\end{array}$ & $\begin{array}{l}\text { TBSA Burn } \\
61-70 \%\end{array}$ & $\begin{array}{l}\text { Total No. } \\
\text { Patients }\end{array}$ & Percentage & $\begin{array}{l}\text { Average } \\
\text { Bed Days }\end{array}$ \\
\hline & $<7$ days & 14 & 6 & 0 & 20 & $10.6 \%$ & \\
\hline & 8-14 Days & 24 & 15 & 3 & 42 & $22.4 \%$ & \\
\hline \multirow[t]{4}{*}{ Block A } & 15-30Days & 32 & 26 & 5 & 63 & $33.6 \%$ & 35.5 DAYS \\
\hline & $>30$ Days & 40 & 16 & 6 & 62 & $33.1 \%$ & \\
\hline & TOTAL & 110 & 63 & 14 & 187 & & \\
\hline & $<7$ Days & 35 & 10 & 5 & 50 & $15.0 \%$ & \\
\hline \multirow[t]{4}{*}{ Block B } & 8-14 Days & 68 & 64 & 6 & 138 & $41.4 \%$ & 24.4 DAYS \\
\hline & 15-30 Days & 61 & 29 & 16 & 106 & $31.8 \%$ & \\
\hline & >30Days & 18 & 19 & 2 & 39 & $11.7 \%$ & \\
\hline & TOTa1 & 100 & 100 & so & 000 & & \\
\hline$\chi 2=2.057$ & $P=0.1515$ & & & & & & \\
\hline
\end{tabular}

References Références Referencias

1. Joan Weber, Albert McManus, Nursing Committee of the International Society for Burn Injuries: INFECTION CONTROL IN BURN https://www. worldburn.org/documents/infectioncontrol.pdf

2. B A Pruitt Jr 1, A T McManus, S H Kim, C W Goodwin World J Surg Burn wound infections: current status: 1998 Feb; 22(2): 135-45. doi: $10.1007 /$ s002689900361.

3. Yusuf Kenan Coban; Infection control in severely burned patients World J Crit Care Med. 2012 Aug 4; 1(4): 94-101. doi: 10.5492/wjccm. v1. i4.94

4. Pauline Jumaa: Prevention of Infection in Burns Units British Burn Association (BBA) and Healthcare Infection Society (HIS) https:// www.theific.org/wpcontent/uploads/2017/10/ 12.pdf 
5. Peck MD, Weber J, McManus A, Sheridan R, Heimbach D: Surveillance of burn wound infections: a proposal for definitions. J Burn Care Rehabil. 1998; 19: 386-389. [PubMed]

6. Neelam Taneja, Rekha Emmanuel, P. S. Charie, Meera Sharma: A prospective study of hospitalacquired infections in burn patients at a tertiary care referral center in North India: Burns Volume 30, Issue 7, November 2004, Pages 665-669.

7. Garner JS, Jarvis WR, Emori TG, Horan TC, Hughes JM. CDC definitions for nosocomial infections, 1988. Am J Infect Control. 1988; 16: 128-140. [PubMed] [Google Scholar]

8. Joan M Weber: Infection control in burns patients, July, 2006; E: jweber@partners.org

9. Barret JP, Herndon DN. Modulation of inflammatory and catabolic responses in severely burned children by early burn wound excision in the first 24 hours. Arch Surg. 2003; 138: 127-132. [PubMed] [Google Scholar]

10. Hart DW, Wolf SE, Chinkes DL, Beauford RB, Mlcak RP, Heggers JP, Wolfe RR, Herndon DN. Effects of early excision and aggressive enteral feeding on hypermetabolism, catabolism, and sepsis after severe burn. J Trauma. 2003; 54: 755-61; discussion 761-4. [PubMed] [Google Scholar]

11. Sheridan RL, Tompkins RG, Burke JF. Management of burn wounds with prompt excision and immediate closure. J Intensive Care Med. 1994; 9:6-17. [PubMed] [Google Scholar]

12. Oncul 1, E Ulkur, A Acar, V Turhan, E Yeniz, Z Karacaer, $F$ Yildiz: Prospective analysis of nosocomial infections in a burn care unit, Turkey; Indian J Med Res. 2009 Dec;130(6): 758-64

13. Pia Appelgren 1, Viveca Björnhagen, Katarina Bragderyd, Carl Evert Jonsson, Ulrika Ransjö: A prospective study of infections in burn patients; Burns;. 2002 Feb; 28(1): 39-46. doi: 10.1016/s03054179(01)00070-5.

14. Tancheva D, Hadjiiski O. Effect of early nutritional support on clinical course and septic complications in patients with severe burns. Ann Burns Fire Disasters. 2005; 18:74-78. [PMC free article] [PubMed] [Google Scholar] 